\title{
Customer E-Satisfaction Towards E-Retailing Services in Salem City
}

\author{
M. Abirami
}

\begin{abstract}
In a global era marketing environment have been startup with the smart ways to promote their product via internet. The fast growth and development of the internet has a very strong impact upon the worldwide marketing environment. In recent trends it has become one of the very most popular approaches for business and customer to perform trading over the internet. Though e-commerce has created new path to businesses as well as customers, it is all about the consumer attitude towards business to commerce (B2C) vis-a-vis the conventional shopping channel to persist. Moreover, the success of e-retailing depends on the customer satisfaction during their purchase. This study is taking place to identify the customer's e-satisfaction level in e-retailing services. The result of this research study reports the customer e-satisfaction towards e-retailing services channels through constructs prescribed by the frameworks. Using constructs, a model was tested among the e-retailing customers and to find their satisfaction and preferences.
\end{abstract}

Keywords : E-Commerce, E-Retailing, E-Satisfaction.

\section{INTRODUCTION}

The electronic retailing is also called as e-retailing or internet retailing. E-retailing is the process of selling the goods and services through electronic media. Particularly, the internet is the main source by which electronic retailing is practiced. To simply state, when the retailing sale of goods and services take place online it is called e-retailing. It falls under B2C business model in e-commerce. It plays vital role in connecting customers and business directly without the involvement of intermediaries. In recent days, e-retailing is more popular with the increase in the usage of world wide web called as www. To understand the customer's need for online selling has become a very big challenge for marketers. Especially, for better understanding of the consumer's attitudes towards e-retailing is very essential. Making improvement in the factors that influence consumers to shop online and working on factors that affect consumers to shop with e-retailers will help marketers to gain the competitive edge over others.

Nowadays, e-retailing is in the rapid growth phenomenon. The fast growing numbers of customers in using e-retailing to shop their goods and services, makes the customers to collect many information about the product, and also provides them an enjoyment during browsing online. E-retailing environment plays a very significant role in bridging the relationship between business and their customers. E-retailing is mainly depends on the cyberspace that provides the appearances such as images, pricelist, pictures, more number of quality information, and best video clips of the product, number of collections, but not the actual experience. According to the survey data of clicks statistics, the number of internet users over worldwide is expected to increase to 1.9 billion by 2015 . The internet has become a truly global phenomenon, and the diverse of internet population, their wide use of internet and the rapid growth of technology have created a new and wide market for both the customers and business.

\section{STATEMENT OF THE PROBLEM}

E-retailing has gained a lot of importance in present marketing conditions. But along with its vital growth the number of scamps, fraudulent practices and cheating also increased. Such cheating activities had created fear in the minds of customers and also an adverse impact in the attitude of consumers towards online purchase. The problem area of this survey is consumer's e-satisfaction and attitudes towards e-retailing will determine the factors that influence customers to shop online and those factors will help the marketers to their strategies towards e-retailing services.

\section{OBJECTIVES}

- To identify the customers e-satisfaction towards e-retailing services.

- To find the specific motto of customers choice on e-retailing services.

- To identify the mode of payment in which customers of e-retailing are more satisfied.

\section{SCOPE}

- Identify the most popular e-retailer and level of customers e- satisfaction.

- To know why people prefer buying through e-retailing.

- To identify the payment mode that preferred by salem city people.

\section{LIMITATION}

- The study is confined only to Salem city.

- The study is based only upon the consumer attitude on e-retailing services. 
- The data collected for the research is fully on primary data given by the respondents. There is a chance for personal bias. So the accuracy may or may not be correct.

\section{LITERATURE REVIEW}

Based on the study, Jyoti Arora is a listing of some of the main findings and recommendations for the proposed policy agenda: A best $24 \times 7 \times 365$ customer service through email, chat and toll free number facility is what the e-retailers are providing. The objective of website should be to increase public awareness and cognizance of company's name, brand, or identity and make product information available to customers and/or distributor. Consumer do not think twice before buying a clothing item from a trusted and tried out brand because the fit and touch is already known. The steps also need to be taken by sorting out the issues of security and payments. In modern scenario, e-retailing or online shopping has become part and parcel of the people in India. And e-Retailing in India can be a success if the e- retailers change their business models and understand their consumer more because consumer are the real Kings. It is inevitable to create a sustainable environment mechanism for futuristic growth of e-retailing in India. Arora (2013) observes that 10 percent of e- commerce growth in India is contributed by e-retailing segment. This growth is observed to be contributed by the factors such as cognizance, Internet literacy and wider use of Internet among the customers. Further, the above study observes advantages like time saving for the urban customers and retailers in e-retailing format comprising the website supplementing the frontline employee of physical format. Despite these advantages, the above study highlights issues like lack of personal touch and bargaining possibility and poor e-illiteracy among rural India as the major limiting factors for the sustainable growth in e-retailing sector.

\section{RESEARCH METHODOLOGY}

\section{A. Research Design}

The research design used for the study is descriptive. Descriptive research studies are those, which are concerned with describing the characteristics of a particular individual or group. The studies concerned with specific prediction with narration of facts and characteristics concerning individual group or situation are all examples of descriptive research studies.

Size of the Population: The total population size is indefinite.

Size of the Sample: This refers to the number of items to be selected from the total population to constitute the sample. The sample size used for study is 212 .

Design of the Sample: It is a definite plan for obtaining a sample from a given population. It refers to the technique the researcher adopts in selecting items for the sample. The respondents are selected based on convenient sampling.

Tools Used: The data collected through questionnaires were analyzed using simple percentage analysis ranking analysis and Chi-square test.

\section{DATA ANALYSIS AND INTERPRETATION}

A sample of 250 customers has been surveyed, out of which 212 questionnaires are fit for analysis. By using SPSS, this research uses some of the basic tools to analyses and to find the level of satisfaction, which makes them to buy.

Table - 1: Demographic Profile of the Respondent

\begin{tabular}{|c|c|c|}
\hline Demographic Profile & $\mathbf{N}$ & $\begin{array}{c}\text { Percentage } \\
(\%)\end{array}$ \\
\hline \multicolumn{3}{|l|}{ Gender } \\
\hline Male & 110 & 52 \\
\hline Female & 102 & 48 \\
\hline \multicolumn{3}{|l|}{ Age (Year) } \\
\hline$<20$ & 15 & 7 \\
\hline $21-30$ & 39 & 18 \\
\hline $31-40$ & 71 & 34 \\
\hline $41-50$ & 48 & 23 \\
\hline Above 50 & 39 & 18 \\
\hline \multicolumn{3}{|l|}{ Educational Qualification } \\
\hline Up to Higher Secondary & 19 & 9 \\
\hline Diploma & 24 & 11 \\
\hline Under Graduation & 53 & 25 \\
\hline Post-Graduation & 78 & 37 \\
\hline Professional & 38 & 18 \\
\hline \multicolumn{3}{|l|}{ Occupation } \\
\hline Business & 32 & 15 \\
\hline Govt. Service & 76 & 35 \\
\hline Private Service & 45 & 21 \\
\hline Student & 29 & 14 \\
\hline Home Maker & 30 & 14 \\
\hline \multicolumn{3}{|l|}{ Monthly Income (Rs.) } \\
\hline Below 10,000 & 8 & 4 \\
\hline $10,001-20,000$ & 23 & 11 \\
\hline $20,001-30,000$ & 29 & 14 \\
\hline $30,001-40,000$ & 54 & 25 \\
\hline Above 40,000 & 98 & 46 \\
\hline \multicolumn{3}{|l|}{ No. of Members in the Family } \\
\hline Upto 2 & 32 & 15 \\
\hline 3 & 46 & 22 \\
\hline 4 & 71 & 34 \\
\hline 5 & 43 & 20 \\
\hline Above 5 & 20 & 9 \\
\hline \multicolumn{3}{|l|}{ Marital Status } \\
\hline Married & 128 & 60 \\
\hline Unmarried & 84 & 40 \\
\hline
\end{tabular}

Interpretation: The survey data reveals that $52 \%$ of the respondents are male. The majority (34\%)of the respondents in the age group between $31-40$ years. 
Out of the total respondents $37 \%$ are post graduate level which is majority. And it is disclosed that the most of them are engaged in government services $(35 \%)$. We found that the monthly earning of the majority respondents (46\%) is above Rs.40,000. Most of the respondents (34\%) are belonging to the nuclear family with four members. Out of the total $60 \%$ of the respondents are married.

Table 2: The most popular E-retailers websites visited and used by the respondents

\begin{tabular}{|c|c|c|}
\hline E-Retailers & N & \% \\
\hline Flipkart & 41 & 19 \\
\hline Amazon & 78 & 37 \\
\hline eBay & 20 & 9 \\
\hline Myntra & 18 & 8 \\
\hline Snapdeal & 31 & 15 \\
\hline Olx & 18 & 8 \\
\hline Others & 6 & 3 \\
\hline Total & 212 & 100 \\
\hline
\end{tabular}

Interpretation: From the table it is found that $37 \%$ of the respondents used and preferred Amazon, 19\% of the respondents prefer Flipkart, $15 \%$ of the respondents prefer to use Snapdeal, 9\% of the respondents visited and used eBay, $8 \%$ of the respondents prefer Myntra \& Olx, 3\% of the respondents visit and use other websites for e-retailing services.

Table 3: Preference of the respondents towards E-retailing

\begin{tabular}{|c|c|c|}
\hline Preference & N & \% \\
\hline Time saving & 55 & 26 \\
\hline Less Expensive & 42 & 20 \\
\hline Less Stress & 20 & 9 \\
\hline Best Offers & 33 & 16 \\
\hline Easy Ordinary System & 16 & 8 \\
\hline Helpful for Old \& Disabled & 19 & 9 \\
\hline Service Quality & 27 & 12 \\
\hline Total & 212 & 100 \\
\hline
\end{tabular}

Interpretation: From the above table it I observed that $26 \%$ of the customers prefer e-retailing services for the purpose of time saving, $20 \%$ of the customers are preferring e-retailing because it is less expensive, $16 \%$ of them use e-retailing because of its best offers, $12 \%$ of them prefer e-retailing for the best services provided by the e-retailers, $9 \%$ of the others prefer e-retailing for less stress and it is helpful disabled and old age people, and finally the $8 \%$ of them prefer e-retailing for its easy system.

Table 4: The mode of payment preferred by the respondents

\begin{tabular}{|c|c|c|}
\hline Mode of payment & $\mathbf{N}$ & $\mathbf{\%}$ \\
\hline Debit cards & 39 & 18 \\
\hline Credit cards & 32 & 15 \\
\hline Online bank transfer & 43 & 20 \\
\hline
\end{tabular}

\begin{tabular}{|c|c|c|}
\hline Cash on delivery & 98 & 46 \\
\hline Total & 212 & 100 \\
\hline
\end{tabular}

Interpretation: The above table reveals that $46 \%$ of the respondents prefers to make payment by cash on delivery, $20 \%$ of the respondents make payment through online banking services, $18 \%$ of the respondents make payment through debit cards, $15 \%$ of the respondents make payment through credit cards.

Table 5: Respondents experience towards e-retailing

\begin{tabular}{|c|c|c|}
\hline Level of experience & N & \% \\
\hline Highly satisfied & 38 & 18 \\
\hline Satisfied & 113 & 53 \\
\hline Neither satisfied nor dissatisfied & 52 & 25 \\
\hline Dissatisfied & 9 & 4 \\
\hline Highly dissatisfied & - & - \\
\hline Total & 212 & 100 \\
\hline
\end{tabular}

Interpretation: The above table reveals that $18 \%$ of the respondents highly satisfied with e-retailing, $53 \%$ of the respondent satisfied with e-retailing services, $25 \%$ of the respondent neither satisfied nor dissatisfied with e-retailing services.

Table 6: Satisfying factors that drives the customers to utilize e-retailing

\begin{tabular}{|c|c|c|c|}
\hline $\begin{array}{c}\text { Satisfying factors that } \\
\text { drives }\end{array}$ & $\begin{array}{c}\text { Frequenc } \\
\mathbf{y}\end{array}$ & $\begin{array}{c}\text { Mean } \\
\text { value }\end{array}$ & Rank \\
\hline Social connection & 12 & 0.48 & III \\
\hline Status conscious & 15 & 0.6 & II \\
\hline $\begin{array}{c}\text { Connection with the } \\
\text { product }\end{array}$ & 3 & 0.12 & V \\
\hline Emotional urgency & 7 & 0.28 & IV \\
\hline Anxiety & 20 & 0.8 & I \\
\hline
\end{tabular}

Interpretation: The table reveals that the mean value of the frequency and the ranking among them. It is clearly shown that anxiety is the most important factor that drives the customers towards using e-retailing services. Status consciousness and the social connection ranked second and third respectively. Emotional urgency and connection with the product ranked fourth and fifth respectively.

Table 7: Relationship between the factors (e-retailing vs e-satisfaction) - Chi-Square Test

\begin{tabular}{|c|c|c|c|}
\hline & VALUE & df & $\begin{array}{c}\text { Asymp.Sig. } \\
\text { (2-sided) }\end{array}$ \\
\hline $\begin{array}{c}\text { Pearson } \\
\text { Chi-Square }\end{array}$ & $.656 \mathrm{a}$ & 3 & .003 \\
\hline Likelihood Ratio & .660 & 3 & .883 \\
\hline $\begin{array}{c}\text { Linear-by-Linear } \\
\text { Association }\end{array}$ & .146 & 1 & .702 \\
\hline $\mathrm{N}$ of Valid cases & 212 & & \\
\hline
\end{tabular}

\section{Inferences}




\section{H0: There is no relationship between satisfying factors and usage of e-retailing services.}

\section{H1: There is a relationship between satisfying factors and usage of e-retailing services.}

From the above analysis, it is found that the $\mathrm{p}$ value is more than 0.05(0.003). Therefore, we reject null hypothesis that there is a relationship between these factors, which aids the e-retailing services will increase high. This also implicates that these factors inspire further for usage of e-retailing services more by the customers.

\section{FINDINGS}

The study identified that the mostof the respondents are male.

People between 31-40 years age group are using e-retailing services.

The education qualification of the respondent is collegiate higher education (PG).

The most of the respondents are belonging to the government service.

Those who are having monthly income above Rs.40, 000 using e-retailing services more.

Those married and belongs to Nuclear family with four members are the majority users of e-retailing.

Most of the respondents prefer Amazon.com.

The purpose and preference of e-retailing is 'for time saving'.

Most of them do purchase through e-retailing on monthly basis.

First rank given by the respondents for theanxiety in making purchases through e-retailing.

Majority of the respondents make payment through Cash on delivery in e-retailing services.

Hence, the majority of the respondent are satisfied with e-retailing services.

\section{CONCLUSION}

In a global era, internet is not just another medium to get in touch with customers, but it is an important channel to find potential customers as well as channel to continue relationship with existing customers. Essentially, the idea of e-retailing is lead the customers to a convenient way of shopping. Customers will be able to save both money and time, plus retrieve all the product information with just few clicks in few minutes. Therefore, purchasing of goods and services can be done anywhere, anytime according to their convenience and preferences.

To conclude, having access to e-retailing has truly revolutionized and influenced our society as a whole. Use of hi- technology has opened new doors and opportunities that enable people to lead a more convenient lifestyle. Variety, quick service and reduced prices were three significant ways in which e-retailing influenced people from all over the world. However, this concept of electronic retailing to the possibilities of fraud and privacy conflicts. Unfortunately, it is possible for criminals to manipulate the system and access personal information. Luckily, today with the latest features usage of hi-technology, proper measures are being taken in order to stop criminals and hackers from inappropriately accessing private databases. Through privacy and security policies, website designers are doing their best to put an end to this unethical practice. By doing so, society will continue to depend upon online e-retailing, which will allow it to remain a tremendous success in the future.

\section{REFERENCES}

1. Palmer, Kimberly, "More Consumers Using Tablets to Holiday Shop Study". December 8, 2011

2. Peterson RA, Balasubramanian S, Bronnenberg BJ. 'Exploring the implications of the Internet for consumer marketing'. Retrieved June, 28, 1997.

3. "Nielsen Global Online Shopping Report". Blog.nielsen.com. 2010-06-29. Retrieved 01, 19, 2012.

4. Campbell DJ. Task complexity: A review and analysis. Academy of Management Review, 13, 1, 1998.

5. Stephen F. King en Juhn- Shiuan Liou, "A framework for internet channel evaluation", International Journal of Information \& Management. March, 24, 2004.

6. 'International Journal of Applied Research 2015; 1(8): 489-495 'A Study on Customer Satisfaction towards Online Shopping' P. Jayasubramanian, D. Sivasakthi, Ananthi Priya K.

7. IOSR Journal of Computer Engineering (IOSR-JCE) e-ISSN: 2278-0661, p- ISSN: 2278-8727Volume 10, Issue 3 (Mar. - Apr. 2013), PP 11-15 www.iosrjournals.org www.iosrjournals.org Prospect of 'E-Retailing In India' Jyoti Arora

8. IOSR Journal of Business and Management (IOSR-JBM) e-ISSN 2278-487X, p-ISSN: 2319-7668. Volume 17, Issue 3.Ver. III (Mar 2015), PP 31-37 www.iosrjournals.org 'An Empirical study on e-Retailing in India' Adil Rasool and Dr.P.Rajmohan.

9. International Journal of Human Resource Management and Research (IJHRMR) (ICGBS'18) Issue dated13 \&14 December,2018. Vol,8, special issue.'A millennial customer behavior towards impulsive buying'.

10. Electronic Retailing (E-tailing)Reviewed by Marshall Hargrave updated May 31, 2019

11. Investopedia - Business essentials Proposed Model explaining the Antecedents and Consequent of satisfaction https://businessjargons.com/electronic-retailing.html

12. An International Journal Volume 3 Number 1 Summer 2008 23. The Relationship among e-Retailing Attributes, e- Satisfaction and e-Loyalty. $\mathrm{Ki}-\mathrm{Han}$ Chung School of Business Gyeongsang National University Jinju 660-701, Korea Email: khchung@gnu.ac.kr Jae-Ik Shin School of Business Gyeongsang National University Jinju 660-701, Korea Email: sji@gnu.ac.kr

13. A Study of E-retailing: Analysing the Factors and Perceptions of Indian Millennials for Online Retailers. IMR (Indira Management Review) Volume XI, Issue I, July, 2017. Yogesh D Mahajan Associate Professor, Indira School of Business Studies, Pune

\section{AUTHOR PROFILE}

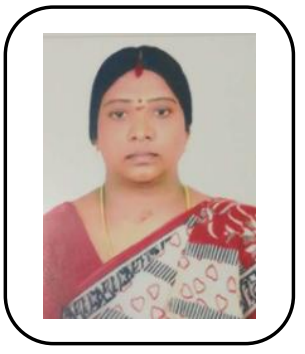

Dr. M. ABIRAMI, is working as Assistant Professor in commerce, Sri Sarada College for Women, Salem. She has been teaching commerce for more than two decades. She has completed her Under-Graduation, Post-Graduation and Master of Philosophy in commerce from University of Madras. She has completed her Master of Business Administration with specialization in Marketing from University of Madras and her Doctorate in commerce from Bharathiya University. She has also completed her NET in commerce. She has started her carrier as Lecturer in commerce in Sri chandrasekherendraSaraswathiVishvaMahavidhyalaya, Deemed University, a cell at Pammal. Later, she joined DRBCCC Hindu College, Pattabiram, Chennai as a Assistant Professor in commerce and corporate secretaryship and handled both Under-Graduate and Post-Graduate of commerce and corporate secretaryship. 
She has been Head and Assistant Professor of Corporate Secretaryship for seven years. She has been acted as an external examiner, for Under-Graduate project Viva-voce for many years. And also been a valuation examiner in various colleges for many times. She has presented and published six international papers, four national papers and two state-level papers. She has participated in many conferences, workshops, seminars, symposiums and faculty development programmes. She has been a question paper-setterof commerce and corporate secretaryshipin various colleges. She is also a member of board of studies in various colleges. Now, she is handling Under-Graduate, Post-Graduate and guiding M.Phil scholars in commerce. 